SCANDALIZE MY NAME 
FORDHAM UNIVERSITY PRESS NEW YORK 2017

COMMONALITIES

Timothy C. Campbell, series editor 


\section{SCANDALIZE MY NAME}

Black Feminist Practice and the Making

of Black Social Life

TERRION L. WILLIAMSON 
Copyright (C) 2017 Fordham University Press

All rights reserved. No part of this publication may be reproduced, stored in a retrieval system, or transmitted in any form or by any means-electronic, mechanical, photocopy, recording, or any otherexcept for brief quotations in printed reviews, without the prior permission of the publisher.

Fordham University Press has no responsibility for the persistence or accuracy of URLs for external or third-party Internet websites referred to in this publication and does not guarantee that any content on such websites is, or will remain, accurate or appropriate.

Fordham University Press also publishes its books in a variety of electronic formats. Some content that appears in print may not be available in electronic books.

Visit us online at www.fordhampress.com.

Library of Congress Cataloging-in-Publication Data available online at catalog.loc.gov.

Printed in the United States of America

$191817 \quad 54321$

First edition

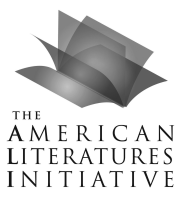

A book in the American Literatures Initiative (ALI), a collaborative publishing project of NYU Press, Fordham University Press, Rutgers University Press, Temple University Press, and the University of Virginia Press. The Initiative is supported by The Andrew W. Mellon Foundation. For more information, please visit www.americanliteratures.org. 
For Grammy 
This page intentionally left blank 